\title{
Text as Discourse: \\ The Chinese in Canada in Historiographical Perspective
}

\section{Samantha J. Scott}

As a historiographical analysis, this essay seeks 10 understand the idea of historical layering through the topic of Chinese immigration to Canada. It considers the following four works: In the Sea of Sterile Mountains: The Chinese in British Columbia (1974) by James Morton. White Canada Forever: Popular Attitudes and Public Policy Toward Orientals in British Columbia (1978) by W. Peter Ward, From China to Canada: A History of the Chinese Communities in Canada (1982) by Harry Con et al., and The Concubine's Children (1994) by Denise Chong. It does so in an efforl to compare and contrast their approaches with regard 10 consensus and specialist histories, top-down and bottom-up approaches, as well as passive and active historical representations.

A palimpsest is a text visible only in patches, trapped beneath etchings of subsequent turitings. Medieval scholars re-used writing parchinents to save money and time; more recently, post-colonial scholars refer to palimpsest as the displacement of local histories with hegemonic discourse. Looking at the stacks of books piled high upon library shelves, I query that surely this is not the case with current westem scholarship. Do new publications actually cover up older texts? This paper takes the perspective that present scholarship ideally engages in dialogue with past research and historical sources. As such, historians play an important role as they write about the past. They participate in a process of intellectual discourse through which later works build upon earlier ones and through which future histories take shape. Thus, historiography expands. The study of the Chinese in Canada is no exception.

This essay treats works by James Morton, ${ }^{1}$ Peter Ward, ${ }^{2}$ Harry Con et al. ${ }^{3}$ and Denise Chong through historiographical analyses by comparing them with three main dichotomies: consensus/specialist histories, top-down/bottom-up perspectives and passive/active historical representations. Generally, as these works show, the historiographical trend moves away from the consensus/topdown/passive toward the specialistbotton-up/active. This essay treats each in ascending order of publication from 1974 to a more recent past in order to

\footnotetext{
'James Morton, In the Sea of Sterile Mounlains: The Chinese in British Columbia (Vancouver: J.J. Douglas Ltd. 1974).

'W. Pcter Ward. While Canada Forever: Popular Altitudes and Public Policy 10ward Orientals in British Columbia (Montreal: McGill-Queen's University Press, 1978).

${ }^{3}$ Harry Con et al.. From China 10 Canada: A History of the Chinese Communiries in Canada (Toronto: McClelland \& Stewart. 1982).

${ }^{4}$ Denise Chong. The Concubine's Children (Toronto: Viking. 1994).
} 
demonstrate these trends. These cases have been selected because each is a published contribution to the literature about the Chinese in Canada in book format. Throughout, this analysis bears in mind a number of questions. What methodologies have been einployed? What assumptions underlay these rexts? How valid are the framcworks in which each historian has presented his/her argument? While comparing these case studies, this essay refers 10 other works about the Chinese in Canada and generates a more general discussion of historiographical issues. It touches upon the nature of sources and perspectives and proposes areas for future discourse about the Chinese in Canada.

Framing this analysis with dichotomies is not intended to suggest that only extreme black and white opposites can explain these case studies. Rather, the distinctions are in shades of grey. Nevertheless, such binary oppositions lend themselves nicely to a conceprial understanding of difference among these texts. Broadly speaking, each opposition represents ways of perceiving history. An analogy of optical lenses illustrates the debate between consensus and specialist historians. Whereas consensus historians peer through a telescope aimed at the expansive night sky, specialist historians squint through a microscope positioned over a subject in a petri dish. Consensus historians structure meta-nanatives based on broad themes and subjects but are criticized for failing to adequately account for diversity. Specialist historians break down themes and subjects into more sizeable portions for closer study but are accused of losing sight of larger historical perspectives.

Do consensus and specialist approaches tuly differ that greatly? It is the ultimate task of any historian to downsize an enormous scope of time, geography and events. It seems that these approaches differ only by the degree to which their lenses are focused. There can even be inade a strong case that the writings of many current histories already blend the best of both approaches. For example, many specialist historians contextualize their micro-level interpretations with links to broader historical understandings. Browse virtually any current copy of an academic historical joumal and this becomes apparent. Furthermore, how barebones would a consensus history be without evidence of micro-level historical examples to support macro-level findings?

Top-down and bottom-up approaches are also ways of perceiving history. Westem scholarship has traditionally served the interests of elites, often using national, political and military formats to the almost entire exclusion of women, the poor, ethnic minorities and youths. Similar to subaltern studies methodology, a bollom-up approach seeks to inverse this relationship, flipping power structures up-side down in effor to expose those histories previously ignored. ${ }^{5}$ Ultimately, a balance must be struck among the experiences of many.

Finally, the third unit of analysis considers the divide berween passive and active representations. A passive voice is like a theatre production based on a true

\footnotetext{
'For discourse about subaltem studies refer to works by Gyan Prakash.
} 
story in which the lines of the main character have been written and directed by someone else. An active historical voice instead takes center stage; an active voice demonstrates agency over the unfolding of his/her own history. This approach to passive/active voices is adopted from Patricia E. Roy's reflections about the historiography of the Chinese and Japanese in British Columbia. ${ }^{6} \mathrm{Her}$ analysis of the historiography is written through the demographic perspective of generations: her findings show that second generation histories, written predominantly from European perspectives, were eclipsed in the 1980s by the third generation who actively wrote their own histories. According to Roy, many third generation Chinese historians continue to tell their histories through "English language monographs, memoirs, oral histories, and anthologies."7

One extreme second generation example is James Morton's In the Sea of Sterile Mountains (1974). For the most part, Morton paints a picture with broad strokes, resulting in a consensus historical approach composed of top-down and passive perspectives. His analysis is predominantly political as the Eurocentric lenses of elite power are filters for interpretation. Needless to say, it leaves no room for the perspectives of the Chinese themselves.

Many of the text's greatest problems result from the methodology and sources. Morton relies at random upon a very minute selection of newspaper articles and government records for which there is little accountability since the work is devoid of footnotes. Given that Morton wrote at a time when access 10 archival materials was limited, it might be argued that he pieced together a picture as best he could. However, Morton's text shows little evidence that he even consulted discourse about the Chinese abroad that was already in circulation before his own publication date. ${ }^{8}$ The lack of footnotes and absence of explicit dialogue with previous texts prove problematic and the conclusions drawn consequently appear unreliable.

Morton's top-down approach is confimmed by his attention to 'big' names in British Columbia's political history. While politicians clearly played an important role in public policies, Morton excludes other players who may have contributed to a more comprelensive understanding of the times. Furthennore, his

\footnotetext{
"Patricia E. Roy. "'White Canada Forever': Two Generations of Studies." Canodian Elhnic Siudies XI, no. 2(1979), 97-109 and "Active Voices": A Tbird Generation of Sudies of the Chinese and Japanese in British Columbia," BC Studies 117 (Spring 1998), 51 -61.

'Roy, "'Active Voices, "' 51.

"Although the topic was by no means completely addressed in the United States by the early 1970s, there were a number of works already published. These included Rose Hum Lee. The Chinese in the Unired States of America (Hong Kong: Hong Kong University Press, 1960): Gunther Barth, Bitler Strength: A History of the Chinese in the United States: 1850-1870 (Cambridge, Massachuselts: Harvard University Press, 1964); Edgar Wickberg. The Chinese in Philippine Life. 1850-1898 (New Haven: Yale University Press, 1965): and Stuan Creighton Miller, The Unwelcome Immigrant: The Americon Image of the Chinese, 1785 1882 (Bcrkeley: University of Califomia Press, 1969).
} 
narrative often denies academic historical conventions. For example, he often casually refers to provincial and municipal politicians, such as Amor De Cosinos and Noah Shakespeare, only by their first names.

Many current analyses frame histories thematically in effort to provide cohesion to the past. In contrast to more recent approaches Morton's analysis perceived of history as a linear progression of cause and effect following a strict chronological frainework. Each chapter is presented as a consecutive set of yearly dates with no explanation for their significance. Numbers and dates are quite meaningless without qualification. This linear approach is proved even further problematic within the analysis. For example, he writes of a disnuption to the "natural evolution of the history of the Chinese in British Colunbia." The very suggestion that the evolution of the Chinese in British Columbia was "natural" problematically implies historical detenninism. In other words, it assumes that history was destined to unfold in such a manner. In defense of Morton, he tries to recognize the shortcomings of his own text. He states rather self-critically that this work is "not a necessarily sociological history of the Chinese...nor... for that matter, a particularly accurate or complete one." 10 The text must be praised for attempting an international scope through loose connections between British Columbia, Califomia and Australia. However, his analysis is political and economic at the expense of an adequate consideration of gender and families. Perhaps on some level Morton cannot be held entirely accountable for these onissions. Women's and gender studies really only broke ground in the discipline of history in the 1970s - not to inention that such topics are still marginalized in many recent texts." Although this text is outdated in many respects, the fact that it confronts discrimination toward the Chinese is testimony to an increasingly liberal climate of opinion. ${ }^{12}$

W. Peter Ward published White Canada Forever: Popular Attitudes and Public Policy Toward Orientals in British Columbia (1978) only four years later. His work is also considered a second generational study, yet its analysis has more

\footnotetext{
${ }^{9}$ Morton. 226.

10 Jbid., viii.

"For an informative discourse on gender and women's history in Canada see the dialogue berween each of Joan Sangster, "Beyond Dicholomies: Re-Assessing Gender History and Women's History in Canada," Lefi Hislon' 3 (1995), 109.122; Karen Dubinsky and Lynne Marks, "Beyond Purity: A Response to Sangster," Lefi Hislory 3\&4 (1995-96), 205-220;

Franca lacovetta and L. Kealey. "Women's History, Gender History and Debating Dicholomies," Lefi Hislory (1995-96). 221-237; and Joan Sangster, "Reconsidering Dicholomies," Lefi Hislory (1995-96), 239-248.

${ }^{12}$ According to Roberto Perin and Dirk Hoerder, studies of ethnicity were ignored in Canadian history before the 1970s. Robeno Perin, "Clio as an Elhnic: The Third Force in Canadian Hisloriography," Canadian Hislorical Review LXIV, no. 4 (1983), 441-467 and Dick Hocrder, "Ethnic Srudies in Canada from the 1880s to 1962: A Historiographical Perspective and Critique," Canadian Elhnic Siudies XXVI, no. I (1994), I-18.
} 
depth beyond the plainly consensus, top-down and passive approaches taken by Morton. For the inost part, Ward's scholarship continues to portray the Chinese passively since it concentrates on what Europeans thought of and how they treated the Chinese. However, Ward does question: "But what of British Columbia's Chinese themselvcs? Was there substance to the inage of the Chinese immigrant? Did appearance and reality converge?"13 Still, the questions only dance on the precipice of including a Chinese perspective. Instead, he skims the surface by trying to challenge some European perceptions while the Chinese remain silent in this work.

Unlike Morton, Ward's work is far more sensitive to bottom-up approaches. This is evident from the title which claims to consider "popular attitudes" as distinct from "public policy." However, Ward weakly attempts to draw parallels between these realms in order to justify his analysis. In other words, he argues that racism was a political issue because British Columbia lacked a "mature and differentiated smacrure of social institutions" to absorb racist ideas; politics were consequently a "natural oudet" for racial thought. ${ }^{14}$ In sum, Ward assumes that racism materialized in govemment politics due to the less developed nature of British Columbia's social structures. This interpretation is greatly flawed, especially in light of parallel attitudes that developed toward the Chinese in other countries. In fact, Roy's article published in 1980, only two years later, indicates that "anti-Asian prejudice occurted alınost everywhere Asians inigrated or sought to migrate."'s Two such countries with very similar policies to Canada were those noted by Morton -- the United States and Australia. Indeed, the governments of each of these countries operated with a close eye to international policies toward the Chinese. ${ }^{16}$

Ward also assumes that there was indeed a general consensus of opinion, especially in terms of what type of settler best fit a 'Canadian' profile. This is indicated by the title White Canada Forever. And while his analysis occasionally observes Ottawa as the seat of federal governinent, it concentrates predominantly on British Columbia to the exclusion of the rest of the country. ${ }^{17}$ The fact that

\footnotetext{
${ }^{13}$ Ward, 14

14 Jbid. 44.

15Parricia Roy, "British Columbia's Fear of Asians." Hisloire Sociale/Social History 13 (1980).

${ }^{16}$ Two informative yel somewhat outdated texts are by Cbarles A. Price, The Great While Walls ale Buill: Restriclive Immigration 10 Norih America and Ausiralasia: 1836-1888 (Canberra: Australian National University, 1974) and Andrew Markus, Fear and Hatred: Purifying Australia and California 1850-1901 (Hale \& Iremonger. 1979).

${ }^{17}$ The majority of studies about the Chinese in Canada focus on British Columbia since most Chinese arrived via this region. For a recent altemative regional study see Zhongping Chen. "Chinese Familism and Immigration Experience in Canadian Towns and Small Cities: From Dual Paradigms on the Chinese in Canada to a Cross-Cultural Srudy of the Case of Peterborough. Ontario. 1892-1951," Asian Profile 32, no. 4 (August 2004), 289-312.
} 
British Columbia herself has typically been considered an outlier in Canadian history hardly advances the assumptions that British Columbia was a litmus test for national opinion. ${ }^{18}$ Furthennore, he frequently uses the phrase "white community" as though one homogenous group of Europeans compared against one homogenous group of Chinese. Nowhere does he define what "white community" means nor who might comprise this imagined collective. Also, Ward"s conclusion indicates that once racial discourse was "ingrained in the white inind," those who took exception with the moral climate simply kept their opinions to themselves. ${ }^{19}$ Yet again Ward idealistically assumes both the piesence of a singular mentality and that the most outspoken members of society actually represented the inajority opinion. However, Ward tries to demonstrate diversity of opinion by injecting the odd claim that it was not likely that all shared these ideas. For example, he shows that "the Chinese were most welcome" employed them as domestic servants.

It is clear that Ward's method is a consensus approach. Yel compared to Morton, Ward forms a more structured historical argument through dialogue with historical sources and previous scholarship. His analysis incorporates recently released archival materials in both British Columbia and Ottawa. A bibliography is lacking, but he diligently footnotes his references and includes a number of tables to support his research. In terms of topics and themes, Ward largely ignores gender and families. Their exclusion is all the more ironic since early Chinese communities were comprised alınost exclusively of single men who came looking for wage labour and gold. ${ }^{21}$ Through more recent scholarship it has emerged that the gender imbalance in Chinese communities was evident from other perspectives. As one example, inany European women perceived jobs accepted by Chinese men (such as servants, launderers and cooks) as "feminized service positions." ${ }^{22}$ British Columbia was thus a place where cross-cultural gender norms were both challenged and confirmed. The title of the first chapter, "John Chinaman," seems to recognize the gendered nature of racial stereotypes, yet the acnial text offers very litrle understanding of the gendered nature of coinmunitics during these tines.

\footnotetext{
${ }^{18}$ British Columbia has long been considered the "spoilt cbild" of Canadian Confederation. Ideas of difference and regionalism are looked at by Philip Resnick. The Politics of Resenment: British Columbian Regionalism and Canadian Unity (Vancouver: UBC Press, 2000). 12.

${ }^{19}$ Ward, 167.

${ }^{20} \mathrm{Ibid} ., 26$.

${ }^{21}$ For an article on Chinese women see Peggy Pascoe. "Gender Systems in Conflict: The Marriages of Mission-Educated Chinese American Women, 1874-1939," Journal of Social History 22. 4 (Seplember 1989), 631-652.

${ }^{22}$ Sheila McManus, "Their Own Couniry': Race, Gender, Landscape, and Colonization around the 49" Parallel. 1862-1900," Agricultural Hislory 73, no. 2 (Spring 1999), 178.
} 
Ward's argument can be placed within the context of North Aunerican historiograpby about the Chinese. The footnotes demonstrate his familiarity with American literanure on this subject. He cites Stuan Creighton Miller's work. The Unwelcome Immigrant: The American Image of the Chinese, 1785-1882 (1969), which challenged the current prevailing interpretations about the roots of racism. Miller argued that racism had roots in the American labour classes as a whole and did not just stem from the regional Califomian labour classes. By engaging such dialogue Ward in rum contributes to the literature by arguing that economics and labour take a backseat to the "social psychology of race relations," that racial ideology permeated more than just one economic class of people. From here, From China to Canada: A History of the Chinese Communities in Canada (1982) by Harry Con et al. takes a middle-of-the-road position, emphasizing both economics and negarive stereorypes about the Chinese as causes of racism.

Both Ward and Con et al. thus seek explanations for the emergence of racist legislation toward the Chinese. Whereas Ward claims these politics materialized because the province lacked developed social networks, Con et al. reason that government policies "normally responded to what were believed to be public sentiments." ${ }^{23}$ Each interpretation inakes the assumption that politics indeed represented public interests. A more recent analysis of the American context by Andrew Gyory challenges each of these explanations. Closing the Gate: Race. Politics, and the Chinese Exclusion ACl (1998) looks closely at the manipulation of government legislation by American politicians, concluding that anti-Chinese laws were used as a distraction for the tom memories of the American Civil War. ${ }^{24}$ Although the Canadian political stmucture differs from the United States, and Canadians participated in no such traumatic national event, the influence of intemational ideas must not be underestimated. In one case the Canadian Royal Commission on Chinese Innmigration of 1885 consulted American imnigration policies to inform much of their resulting repoit. In sum, Ward's text can be criticized on a number of levels, yet even as a study from the second generation, it cuts loose from a number of restrictive formats typical of much previous scholarship.

Representative as a study from the third generation of research, Con et al. offer a more specialized analysis with greater sensitivity to multiple perspectives and methods of representation. They have created a dialogue of multi-linguistic discourse by consulting not only a variety of English language sources, but also a range in Mandarin and Japanese. Even though it remains only "in part a Chinese perspective," ${ }^{25}$ this analysis moves further away from Eurocentric lenses while awarding Chinese voices greater volume. Indeed, the interpretations of Con et al.

\footnotetext{
"Son et al. 269.

${ }^{24}$ Andrew Gyory, Closing the Gate: Race, Politics, and the Chinese Exclusion Acl (Chapel Hill, University of North Carolina Press, 1998).

is Con et al., 2.
} 
are clearly only a partial perspective for they fail to give due consideration to gender and families as a means to understand the history of the Chinese in Canada. Yet while one chapter does include awareness of generational differences berween Chinese parents and their Canadian-raised children, this vignette lacks sufficient attention. That being said, these authors had previously outlined the parameters of their study such that it concentrates on organizations, not individuals, and their ensuing treatment of organizations is an encouraging starting point for scholars on these subjects. It regards the socio-political life of the Chinese while also highlighting the connections between China and the Chinese overseas. Although Con et al. focus mainly on organizations, it is not to the entire exclusion of individuals. For example, they highlight a number of important Chinese individuals and even include mention of instances where Chinese people acted politically beyond their own communities through petitioning and rioting. In this sense their approach is a cross-section of the confluence of both top-down and bottom-up perspectives via different levels of power within these communities and amongst individuals.

The agencies of Chinese organizations and individuals as topics underscore the historiographical trend loward bottom-up approaches and active representations. The first academic text to specifically consider the Chinese as individuals in Canadian historical literanure was Gold Mounlain: The Chinese in the New World (1983) by Anthony B. Chan. ${ }^{26}$ His analysis presents a ChineseCanadian 'insider's view' which builds upon past scholarship by considering racism as an important variable without dwelling upon its manifestations. In other words, it focuses more on the contributions of the Chinese as opposed to the effects of racial injustice on the Chinese. Contrary to Chan, $A$ White Man's Province: British Columbian Politicians and Chinese and Japanese Immigrants, 1858-1914 (1989) by Patricia E. Roy ${ }^{27}$ focuses direcily upon racial injustices. Itself a response to Ward's mainly intellectual analysis, her text illustrates changes in attitudes toward Chinese and Japanese inmigrants through an examination of race relations and politics as expressed principally through primary newspapers.

As an omviscient narrator in The Concubine's Children (1994), Denise Chong draws on family letters, photographs, personal memories and public archival works as sources to support the telling of her family's own story. Since not all stories were the same, she interpreted them as best she could and at times reconstructed past dialogue in order to create what she called a "family project." It can be argued that the very act of composing a family history presunes that there

\footnotetext{
${ }^{26}$ Anthony B. Chan. Gold Mountain: The Chinese in the New World (Vancouver: New Star Books, 1983).

${ }^{27}$ Patricia Roy, A While Man 's Province: British Columbian Politicians and Chinese and Japanese Immigrants, 1858-1914 (Vancouver: Universiry of British Columbia Press, 1989). For the recently published sequel to this text refer to The Oriental Question: Consolidating A White Man 's Province, 19/4-1941 (Vancouver: University of British Columbia Press, 2003).
} 
is one family story 10 be told, yet family members can clain very distinct inemories about the same events. Chong's oinniscient perspective aptly deals with this challenge by incorporating a number of perspectives. Furhennore, Chong editorially comments that her approach to the text was the same "as one might approach the task of restoring a painting - the original canvas was someone else's." 28 Chong remarks about the fluidity of family histories, saying that "such a book is never finished, but that there comes a time when the story is ready to be told. ${ }^{29}$ In this sense, her text self-consciously has no final word but rather represents its own palimpsest. In terms of this paper's analysis, The Concubine's Children is a specialized history based upon bottom-up perspectives and active voices.

Whereas many historical texis focus on a more distant past as a case study, Chong's work brings history to the present by tracing her family history up to her own life. The Chinese in Canada (1998) by Peter S. $\mathrm{Li}^{30}$ also uses the past to contexualize the present. The mainly historical portion of his analysis places heavy emphasis on the establishment of institutional racisin and uses this history to observe its effects on current Chinese coinmunities. A number of other notable works also observe how the past implicates a more recent present. These include Kay Anderson's Vancouver's Chinatown: Racial Discourse in Canada, 1875. 1980 (1991) ${ }^{31}$ and Wing Chung Ng's The Chinese in Vancouver, 1945-1980 (1999). ${ }^{32}$

Whereas many previous texts failed to treat the topics of gender and families wich due consideration, Chang injects these long needed themes into the canon of literature. The majority of the lext is written through the perspecrives of Chinese women, and it demonstrates the value of Chinese familial piery. In one of the most recent issues of Asian Profile Zhongping Chen also addresses the topic of fainily by observing the transfornative effects of foreign customs upon immigrant cultures. ${ }^{33}$ Both Chong and Chen pick up where Con et al. left off in treating the generational divide between first and later generations within Chinese families. ${ }^{34}$

\footnotetext{
${ }^{28}$ Cliong, $x i$.

${ }^{29}$ Jbid., viiii.

${ }^{30}$ Peter S. Li. The Chinese in Canada, $2^{\text {nd }}$ ed. (Toronto: Oxford University Press. 1998).

${ }^{31}$ Kay Anderson. Vancouver's Chinalown: Racial Discourse in Canoda, 1875-1980 (Montreal: McGill-Queen's University Press, 1991).

${ }^{12}$ Wing Chung Ng. The Chinese in Voncouver, 1945-1980: The Pursuit of Identiry and Power (Vancouver: Universiry of British Columbia Press, 1999).

${ }^{33}$ Chen.

${ }^{34}$ R.W. Sandwell argues that families are essential historical units of analysis because historians can situate families as places for aliberal behaviour. This may be even more pronounced in families where private culural practices are maintained amidst public foreign traditions. R.W. Sandwell. "The Limits of Liberalism: The Liberal Reconnaissance and the History of the Family in Canada." Canadian Historical Review 84, no. 3 (2003), 1-18.
} 
What is it that makes such a personal historical format worthy of academic attention? I am reminded of the first written assigninent required of me for an undergraduate Canadian history class. I fully anticipated a standard sign-up sheet listing typical history topics, yet our professor chose a different approach: she expected a paper about our own family pasts, requiring only that we contextualize these personal histories with macro-level details of Canadian historical events. Sudents milling about after class that day stated skeptically: "I thought this was a history class." Indeed, it was. This professor showed us that history takes many forms, and that even personal bistories can fill an important niche in the broader understanding of the discipline of history. Clearly, The Concubine's Children is testimony to this.

A number of fascinating historiographical issues arise from the works of Chong and others. Does bistory have to be written by professionally trained historians? What makes history officially "historical" according to professional historians? The narure and reliability of historical sources is one arena where these debates play out. Oral histories, sources used heavily by Chong, are currently subject to such debate. In many cases the long-standing privilege of the written word in westem scholarship continues to prevail over the oral. On one hand, written text is something tangible to reflect upon and refer back to, whereas verbal words dissipate beyond those ideas caught in listening minds. Yet in many ways text is just as easily subject to misinterpretation and multiple interpretations. Chong appropriately conveys the difficulty in amassing diverse forms of evidence such that "the challenge was to press it flat onto the pages of a book." 35 part from their transmission, how truly different are oral and written styles of history? Both traditions are constructed and both are subject to interpretation. No matter what forn they take, every historical source has its own politics and biases. Whether historians choose to demonstrate their historical convictions in manuscript and footnotes, or share a personal tale from the past to a group of friends, all historians are storytellers on some level.

The research technique of oral interviewing is often subject to close scrutiny. While this method allows individuals to speak directly from their own perspectives, interviewees may not present an honest portrayal of their memories due to many variables. These inay include feelings of intimidation, or feeling it impolite to speak drainarically about their experiences to a stranger. If an interview process adheres too rigidly to pre-determined questions this type of format prevents a free-flowing exchange of ideas often resulting in disjointed narratives and even miscommunication. ${ }^{36}$ In these respects it may have been an advantage that Chong interviewed members of her own fatnily; more candid disclosure may have resulied from these fainilial bonds of trust.

${ }^{35}$ Chong, xi.

${ }^{36}$ For qualitative interviewing techniques see Herbert Rubin and lrene Rubin, Qualitalive Interviewing: The Arl of Hearing Dala (Thousand Oaks: Sage Publications, 1995). 
Selecting valid sources amidst a sea of evidence can often be a challenge; yet an even greater challenge occurs when confronted with too few primary sources. Con et al. benefited from inerchant records; Chong traveled overseas to find letters exchanged between her relatives. When studying the case of Chinese immigration to Canada, many nineteenth cenury Chinese immigrants were illiterate peasants. How 'active' can historians construct their perspectives if these people left little written legacy of their own? How should their sturies be told? Who should tell these stories? Oral histories and oral interviewing provide opportunities for researchers to connect with histories. Evidence of material culture, such as the architecture of Chinatowns, also offers a sense of historical connectedness. Examples of studies in Chinese material culture include Chinatowns: Towns Within Cities in Canada (1988) and Building and Rebuilding Halmony: The Galeway 10 Vicioria's Chinalown (1997) by David C. Lai. ${ }^{37}$ Furthermore, Anglophone historians must overcome linguistic barriers in order to tap into sources written by the Chinese themselves. Linguistic barriers underscore the importance of combining the intellectual efforts of researchers intemationally.

Each of the texts discussed demonstrate a variety of approaches to the topic of the Chinese in Canada. Still, there is much room for further inquiry, especially in terms of immigtation patterns. In order to generate a more coinplete understanding of the Chinese in Canada there is need for comparative analyses with other countries to which the Chinese have migrated. Charles Price made the case for such comparisons since they present opportunities to "see that what at first sight appear to be local oddities are actually inanifestations of wider trends." 38 The observation of dis/continuities annong other former British Empire colonies like Australia and New Zealand and anong other intemational lands like South Africa and Thailand would generate new findings. ${ }^{39}$ It might also prove fruitful to consider Chinese experiences in North Ainerica as a whole or by comparing and contrasting the attirudes and institutional policies of Canada and the United States. ${ }^{40}$ How might knowledge of Chinese diasporas and transnationalisin contribute 10 a greater understanding of the Chinese in Canada? ${ }^{41}$ Placing Chinese

"David C. Lai, Chinarowns: Towns Within Cities in Canada (Vancouver: University of British Columbia Press, 1988); and Lai and Pamela Madofi, Building and Rebuilding Hasmony: The Galeway 10 Vicloria's Chinalown (Victoria: Westem Geographical Press. 1997).

${ }^{38}$ Price, viii.

${ }^{19}$ Wang Gungun, The Chinese Overseas: From Earihbound China to the Quesi for

Auronomy (Cambridge, Massachusetts: Harvard University Press, 2000), 62.

${ }^{40}$ Erika Lee briefly considers the role of borders in a comparative analysis of Canada and the United States in At America's Gales: Chinese Imnigration During the Exclusion Era, 18821943 (London: University of North Carolina Press. 2003).

"For works on these topics see Gungwu. The Chinese Overseas and China ond the Chinese Overseas (Times Academic Press, 1991). 
migrations within contexts of larger historical migrations may lend insight into the push/pull factors that inspired Chinese to leave their homelands. ${ }^{42}$

Diversity of perspective has become an important historical approach; it has become a hallmark of the discipline. The rise of such a hallmark conjures a number of historiographical questions. Namely, whose history is it that is being written? Who is it written by? And who is it written for? The politics of remembrance also becomes a contentious issue. After all, who has the right to speak for others who no longer live to tell their own histories?

An analogy by historical theorist F. R. Ankersmit demonstrates the nuances of perspective in which a number of artists seated at different angles paint representations of the same subject. The subject does not change, yet every painting varies. It is the combination of all perspectives that provides richness to representations of the subject marter. ${ }^{43}$ This essay has itself engaged in a dialogue with secondary sources through an analysis of a number of textual perspectives. Through these processes it has highlighted historiographical trends as research on the Chinese in Canada has expanded over time from the consensus/topdown/passive toward the specialis/bottom-up/active. The open-ended questions throughout this essay are a result of this dialogue and such questions are indications that these srudies have plenty of room for growth. A palimpsest is a process of covering up past texts. Looking at the stacks of books piled high upon library shelves, I realize that past texts have not been covered up, but that dialogue indeed continues.

\footnotetext{
${ }^{42}$ Two such articles include Daniel Gorman, "Wider and Wider Still? Racial Politics, IntraImperial Immigration And the Absence of an Imperial Cirizenship in the British Empire," Journal of Colonialism and Colonial Hisiory 3, no. 3 (2002), 1-47 and Jon Goss and Bruce Lindquist, "Placing Movers: An Overview of the Asian-Pacific Migration System," The Contemporaly Pacific 12, no. 2 (2000). 385-414.

3 F.R. Ankersmit, Hislorical Representations (Stanford: Stanford Universily Press, 2001), 83.
} 